\title{
Nutritional and Health Profiles of the Seasonal Changes in some Nutrients, Anti-nutrients and Mineral Contents of Treculia africana food crop
}

\author{
A. C. Umezuruike, T. U. Nwabueze* \\ Department of Food Science and Technology, College of Applied Food Sciences and Tourism, Michael Okpara University of \\ Agriculture Umudike, Nigeria \\ *Corresponding author: realmira4ac@gmail.com
}

\begin{abstract}
Environmental variables such as temperature, rainfall, sunshine among others are known to influence fruiting, seed formation and quality of food crops by different mechanisms. Levels of nutrients, anti-nutrients and mineral composition of periodically harvested seeds of Treculia africana (a legume) during the fruiting season were assessed to determine the influence of season on quality parameters. Standard methods of analysis were used to evaluate protein, fat, crude fibre, ash, carbohydrate, moisture hydrogen cyanide, phytate, tannin, oxalate, alkaloid, saponinns and minerals. Highest nutritive and anti-nutrient values of seeds occurred at mid season and late season development periods respectively. Observed quality parameters were $14.55 \%$ protein, $5.74 \%$ fat, $2.10 \%$ crude fibre, $1.45 \%$ ash, $33.20 \%$ moisture, $50.14 \%$ carbohydrate, $0.45 \mathrm{mg} / 100 \mathrm{~g} \mathrm{HCN}, 0.8$ phytate $6.10 \mathrm{mg} / 100 \mathrm{~g}, 0.45 \mathrm{mg} / 100 \mathrm{~g}$ $1.65 \mathrm{mg}$ and $0.77 \mathrm{mg} / 100 \mathrm{~g}$ for early season seeds. The mid season seeds quality parameters increases were protein (5.1\%) fat $(0.34 \%)$ ash $(0.22 \%)$, moisture $(2.40 \%)$ carbohydrate $(4.87 \%)$ and mean increase of $3.88 \%$ for antinutrient. Phytate, oxalate and phenolic values were highest at late season seeds. The mineral contents were comparable among the seasons. Calcium $(20.0 \mathrm{mg})$ and magnesium $(280 \mathrm{mg})$ recorded the least values in late season seeds. The relationship between seasonal changes in nutrients, anti-nutrients and seasons was significant $(\mathrm{P}<0.05)$. The quality parameters are within the Recommended Daily Allowance for Nutrients, anti-nutrients and minerals but for calcium and magnesium. The seasonal changes posit Treculia africana as multi-purpose nutritional and health maintenance food crop.
\end{abstract}

Keywords: treculia africana, seasonal changes, chemical composition, nutrition, health

Cite This Article: A. C. Umezuruike, and T. U. Nwabueze, "Nutritional and Health Profiles of the Seasonal Changes in some Nutrients, Anti-nutrients and Mineral Contents of Treculia africana food crop." American Journal of Food Science and Technology, vol. 6, no. 1 (2018): 12-18. doi: 10.12691/ajfst-6-1-3.

\section{Introduction}

Foods of plant origin are important sources of macro and micro nutrients in humans. The ability for food crops to deliver the needed nutrients in human are influenced by environmental conditions. Several studies have attributed the observed changes in chemical composition of food crops to climatic and soil factors during growth and maturity [1,2]. Changes in environmental condition may result to delayed growth, incomplete maturity and loss of quality. Quality parameters such as protein, oil carbohydrate, minerals and anti-nutritional factors are influenced by such factors as temperature, rainfall, sunshine, soil minerals etc [2]. Temperature effects on protein, carbohydrate and lipid formation in legumes are well documented $[1,3]$. However there appears to be some controversies on nutrients accumulation in grains during low temperature and high rainfall accompanying changes in climatic conditions $[4,5]$. The sum hypotheses however implicate variations in climatic factors as responsible for final quality parameters in food crops. Seasonal impacts on quality parameters have been traced to the effects of climatic factors on biochemical processes. Such as formation of chlorophyll, photosynthesis energy transfer, phosphoration, condensation, development of metabolites among others [6,7]. These reactions influence mineral demands and uptakes by growing plants and the resulting deposition patterns of synthesized materials in seeds. The minerals profile of plant soil conditions reflects on the mineral contents of harvested seeds, stems etc.

Treculia africana a legume food crop of the moracaea family, grows in a wide variety of climatic and soil conditions [8] and priced for its nutritive compositions $[9,10]$. The seeds are widely consumed for its nutrients and affordability. Food prepared with Treculia Africana seeds have been successfully used in the management of chronic diseases such as diabetes, obesity, hyper-lipidemia and applied preventively in the management of cardiovascular diseases etc. [11]. The beneficial health factors of Treculia africana were associated with the anti-nutrient of the seeds. However the positive side of the anti-nutrients does not preclude the noted deleterious effects of anti-nutrients on macro and micro-nutrients $[12,13]$. Their anti-nutrient activities such as forming of complexes with starch, 
protein and chelating of minerals are well noted for their limitations on the bioavailability of those nutrients in human digestive tracts $[14,15]$. The successful use of plant, foods as medicinal factors depends on the ability to harness their prime quality parameters, through the identification of proper time of harvest. The fruiting season of Treculia africana spans between October and May. It was hypothesized that there is dependent relationship between chemical compositions, multiple nutritional and health uses of Treculia Africana and climatic variations. The seeds of treculia africana are utilized as food and medicine without proper consideration of the seasonal changes in nutrients, anti-nutrient and minerals. The information on the changes in nutritive components are important for nutrition and also for dietary management of chronic diseases. There is a dearth of information in literature on seasonal changes in some nutritive composition of treculia africana. The objective of the study was to determine how time of harvest during fruiting season affects the quality of Treculia africana seeds. The result of this study will contribute to our understanding of chemical changes due to climatic effects as we strive to exploit the important nutritional and health contributions of Treculia africana to humans.

\section{Materials and Methods}

\subsection{Collection of Materials}

Freshly harvested seeds of African breadfruit were purchased periodically in December, 2013, February, 2014, May 2014 at Umudike, Umuahia Nigeria. The seeds were sourced from the same tree. This was to ensure consistency in stock and variety.

\subsection{Preparation of Sample}

The fruiting seasons of African breadfruit tree crop was divided into Early season seeds ESS (October - December) Mid-season seeds MSS (January - March) and Late season seeds LSS (April - May). The meteorological conditions of the fruiting seasons are summarized on Table 1. The freshly harvested seeds were physically screened for contaminants, shade dried in open trays for 48 hours to constant weight. Three hundred grams of the dried seeds were finely ground with a handmill (Corona SA/CIA) and sieved with $200 \mathrm{~mm}$ mesh into flour. The flour samples were stored in closed plastic containers for proximate, anti-nutrients and mineral element assays.

The preparation of sample was repeated for midseason and late season seeds.

\subsection{Determination of Proximate Compositions}

Proximate composition of sample was determined using the methods as outlined in AOAC [16]. Micro-Kjeldahl method was used for protein analysis, Ether extraction with soxhlet apparatus was used for lipid content analysis. Ash and crude fiber assays used methods No. 08-1 and No.
32-10 of the AOAC [16] respectively. Moisture content was determined using the oven method of analysis. While carbohydrate value was calculated on fractional differential method as carbohydrate $\%=(100-$ fractional components $)$. Energy desirable was estimated using the formula

The estimated Gross Energy value was calculated as

$$
\begin{aligned}
& \text { Gross Energy }(\mathrm{Kj} / 1000 \mathrm{~g}) \\
& =(\mathrm{CP} \times 16.7)+(\mathrm{CHO} \times 37.7)+(\mathrm{EE} \times 37.7)
\end{aligned}
$$

Where

$\mathrm{Kj}=$ Kilojoules; $\mathrm{CP}=$ Crude Protein; $\mathrm{CHO}=$ Carbohydrate; EE = Ether Extract (Lipid); 16.7= Protein factor; $37.7=$ Carbohydrate and Lipid

\subsection{Determination of Anti-Nutrients}

Phytate was determined by the Anion Exchange method. HCN of sample was determined using the colorimeteric methods [16]. Oxalate and Alkaloids were analyzed by methods as described by [17]. Tannin determination employed the spectrophotometric method of Folin - Denis [18].

\subsection{Mineral Assay}

Mineral analysis employed the methods as described in AOAC [19]. After wet digestion, Calcium, magnesium, Iron, Copper, Potassium, Zinc, Phosphorus and Sodium were determined using Atomic Absorption spectrophotometer AAA (Model 372, Perkin - Elmer, Beaconsfield UK) method.

\subsection{Statistical Analysis}

Data obtained from experiments were statically analyzed. Statistical Package for Social Sciences (SPSS. 17.0) was used for Analysis of (variance, standard deviation, Pearson's Correlation etc.) and interpretation of results.

\section{Results and Discussions}

Variations in proximate, anti-nutrient and mineral contents of African breadfruit seeds due to seasons are summarized in Table 2 and Table 3. Some significant differences were indicated in the proximate and antinutrients of the evaluated African breadfruit seeds. The percentage seasonal variations in nutrients, anti-nutrients and minerals are described in Figure 1 - Figure 3.

Table 1. Meteorological Record of Umudike (October 2013-June 2014)

\begin{tabular}{cccc}
\hline Season & $\begin{array}{c}\text { Average Daily } \\
\text { Temperature }\end{array}$ & $\begin{array}{c}\text { Average } \\
\text { sunshine } \\
\text { Hours }\end{array}$ & $\begin{array}{c}\text { Average } \\
\text { monthly Rains }\end{array}$ \\
\hline October - December & $26 \pm 2^{\circ} \mathrm{C}$ & 7 & $120 \mathrm{~cm}$ \\
January - March & $33 \pm 2^{\circ} \mathrm{C}$ & 10 & $50 \mathrm{~cm}$ \\
April - May & $28 \pm 2{ }^{\circ} \mathrm{C}$ & 5 & $180 \mathrm{~cm}$ \\
\hline
\end{tabular}

Source: NRCRI, Meteorological unit, Umudike. 


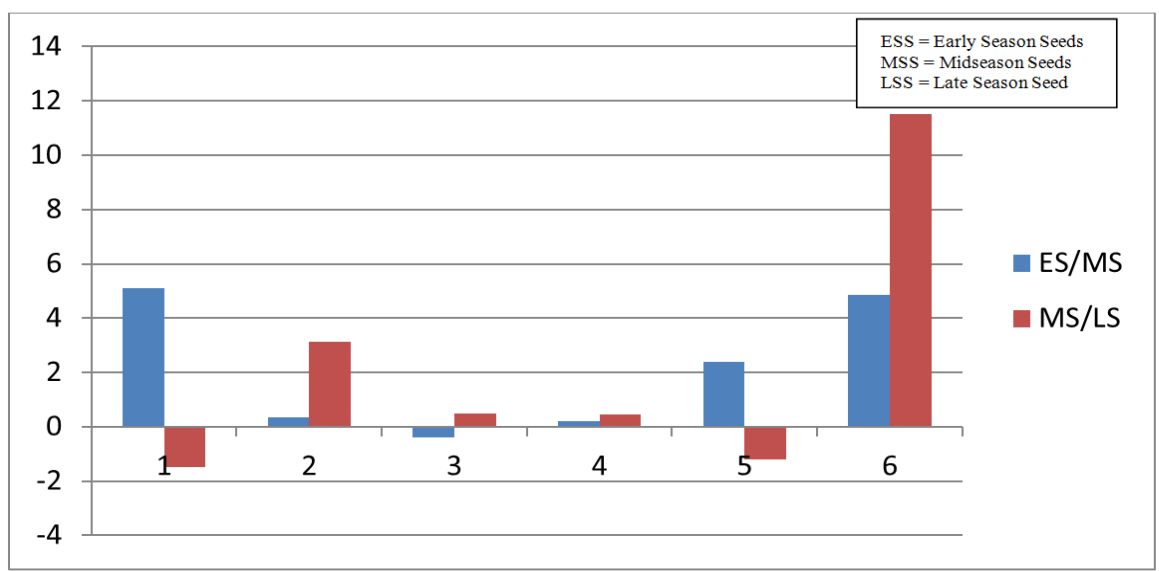

$1=$ Protein $2=$ Fat $3=$ Crude fibre $4=$ Ash $5=$ Moisture $6=$ Carbohydrate

Figure 1. Variations (\%) of Total Proximate Contents by Season

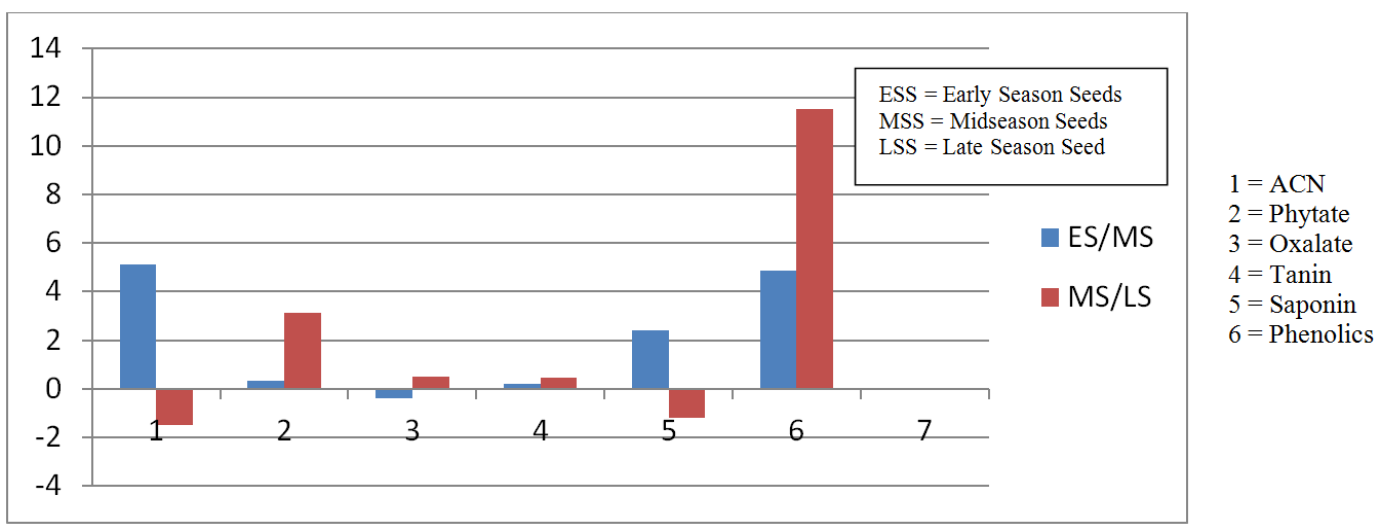

Figure 2. Variations (\%) of Anti-nutrient Contents by Season

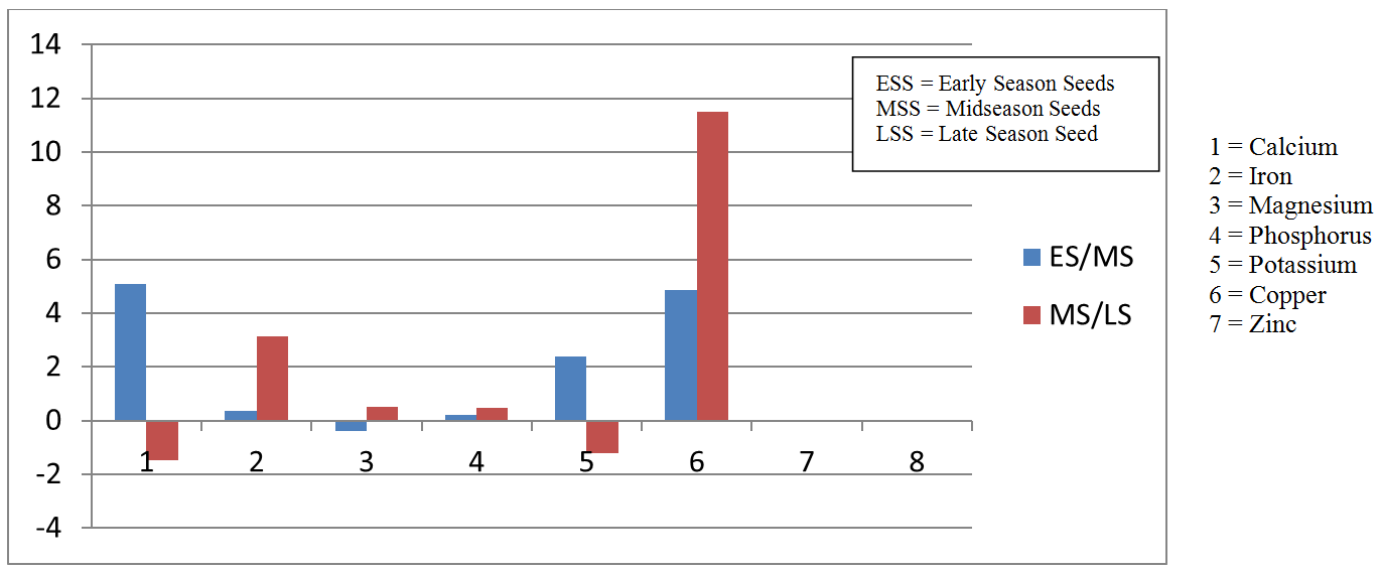

Figure 3. Variations (mg/100g) of Minerals by Season

\subsection{Proximate Composition of Samples}

The average protein content of the samples was 17.4g/100g (Table 1). Protein content of mid season seeds was significantly $(p<0.05)$ higher than the early season seeds (Table 2). Protein content of the late season seeds was $1.47 \mathrm{~g}$ lower than the mid season seeds. The average inter season variation was $18.84 \%$. These results compared favourably with the reported protein content of raw seeds of legume crops [19]; $19.3-21.1 \%$ for African yam beans [27] and higher than the values of $15.2-21 \%$ for Bambara groundnut but lower than the protein content of cowpea [20].
Table 2. Proximate Composition of Seasonal Samples

\begin{tabular}{ccccccc}
\hline \multicolumn{7}{c}{ Seasonal Variation (\%) } \\
Products & ESS & MSS & LSS & Mean & SD & SE \\
\hline Protein & 14.55 & $19.65^{* *}$ & 18.8 & 17.46 & 2.62 & 1.52 \\
Fat & 5.74 & 6.08 & $9.00 * *$ & 7.04 & 1.88 & 1.09 \\
Crude Fibre & 2.10 & 2.50 & 3.00 & 2.36 & 0.05 & 0.32 \\
Ash & 1.45 & 1.67 & 2.13 & 1.76 & 0.31 & 0.22 \\
Moisture & 33.20 & 35.60 & 34.40 & 34.40 & 1.20 & 0.69 \\
Carbohydrate & 50.14 & 55.01 & $66.60^{* *}$ & 57.25 & 8.40 & 4.88 \\
\hline
\end{tabular}

$\mathrm{SD}=$ Standard Deviation, $\mathrm{SE}=$ Standard error of mean

$\mathrm{ESS}=$ Early season seeds

MSS $=$ Mid season seeds

LSS $=$ Late season seeds

** = Significant $(\mathrm{p}<0.05)$ 
Fat content of the late season seeds was significantly $(p<0.05)$ higher than the values for early and mid season seeds (Table 2). The variation in fat content between the late season and early season seeds was $60.28 \%$. Steep rise in fat content from the mid season $(51.32 \%)$ to late season seeds was observed. The fat content of African breadfruit seeds has been reported to be higher than the values for most legumes with the exception of groundnuts, which has an average of $8 \%$ protein content [21].

Crude fibre contents of the different seasons were comparable but slightly higher $(3.00 \mathrm{~g} / 100 \mathrm{~g})$ for the late season. The average seasonal change was $0.45 \%$. Fibre content of African breadfruit seeds agreed with most reports in literature on crude fibre content of legumes seeds [19]. It is higher than the crude fibre of African yam beans, with important gastrointestinal benefits in human

The average moisture content was $34.40 \%$. This value was within the basic water requirement $(35-45 \%)$ by weight needed for maturity of grains [2]. The observed higher moisture content reflected the prevailing rainfall $(150 \mathrm{~mm}-180 \mathrm{~mm})$ pattern of the seasons. Higher rainfall did not appear to delay seed formation and nutrient storage, due to enzyme activations as reported by Salunkhe [4]. Seed formation and maturation occurred through fruiting season.

The average carbohydrate content of the seasons was $57.25 \mathrm{~g} / 100 \mathrm{~g}$. The carbohydrate content of African breadfruit seeds was reported to be higher than most legumes [22] but vary with varieties [23].

These variations in the proximate compositions could be attributed to the prevailing climatic factors affecting $[25,42]$. the seedling process through influence on rainfall, photosynthesis, storage of nutrient etc [1]. Early season proximate nutrient compositions are usually low because of the preferential draw of these nutrients to the leaves [24]. Higher temperatures favoured the accumulation of protein and oil in flax seeds [17]. Androtis et al [1] reported that starch formed at the early fruiting season in oil/seed embryo was transformed into lipids and protein during the seeding process. The higher (9\%) fat content reported reported by this study at low temperature due to increase in rainfall agreed with the findings of Zubr and Mathhaus [1,25] on increased lipid/protein ratio due to formation of lipid following the transcription of fatty acid desaturase gene (FAD). This finding did not agree with the report of Petkova and Antova [17] of high lipid values during high temperature. The seasonal changes in proximate composition indicated an inverse relationship between protein and carbohydrate contents of African breadfruit seeds, probably due to the impact of agronomic or biochemical factors on seed formation and quality [2,17].

Nutritive compositions of African breadfruit seeds no doubt have been demonstrated by various studies to be high and adequately contribute to the energy, protein and mineral requirements of humans. The high values of protein, fat and carbohydrate of the study attest to the important contributions of African breadfruits to human nutrition and health. The average energy value for the seasons was $2715 \mathrm{~kJ}$ which partly satisfies the RDA of $2500-3000 \mathrm{kcal}$ of energy [26]. The crude fibre levels of the samples are indicative good intestinal mobility, and lowering of blood cholesterol due to its hypo-cholesterol effects of crude fibre [7,27]. Similarly high crude fibre assists in efficient management of cancer, diabetes and cardiovascular diseases through its antagonistic effects on nutrients digestion and absorption in the intestine [14]. Daily RDA for crude fibre is $25-50 \mathrm{~g} /$ day. Diet of African breadfruit seeds contributes to the RDA for crude fibre in human. The lipids of African breadfruit seeds have been reported to promote good skin through the rich content of omega-3 and vitamin C [6].

\subsection{Anti-nutrient Content of Samples}

Anti-nutrients are widely distributed in plants as cellular constituents of tissues. These constituents are metabolized into defense factors against predators due to cellular injuries [28].

Variation in anti-nutrient of sample are presented on Table 3 .

Table 3. Anti-nutrient contents of Seasonal Samples

\begin{tabular}{ccccccc}
\hline & \multicolumn{7}{c}{ Seasonal Variation mg/100g } \\
Products & ESS & MSS & LSS & Mean & SD & SE \\
\hline HCN & 0.48 & 0.73 & 1.26 & 0.82 & 0.40 & 0.23 \\
Phytate & 0.80 & 1.60 & 2.30 & 1.51 & 0.75 & 0.43 \\
Oxalate & 6.10 & 8.53 & 8.07 & 7.57 & 1.29 & 0.74 \\
Tannin & 1.98 & 1.96 & 1.17 & 1.70 & 0.46 & 0.27 \\
Alkaloid & 0.47 & 0.40 & 0.33 & 0.40 & 0.07 & 0.04 \\
Saponin & 1.65 & 1.90 & 2.56 & 2.04 & 0.47 & 0.27 \\
Phenolics & 0.77 & 0.57 & 1.80 & 1.05 & 0.66 & 0.38 \\
\hline
\end{tabular}

$\mathrm{ESS}=$ Early season seeds

MSS $=$ Mid season seeds

LSS $=$ Late season seeds

$\mathrm{HCN}=$ Hydrogen Cyanide; $\mathrm{SD}=$ Standard Deviation, $\mathrm{SE}=$ Standard error of mean.

Variations in anti-nutrient values among the seasons were observed. Results (Table 3) showed gradual increases from early to late season. Hydrogen cyanide $\mathrm{HCN}$ values ranged from $0.48 \mathrm{mg} / 100 \mathrm{~g}$; ESS $0.73 \mathrm{mg} / 100 \mathrm{~g}$; MSS to $1.26 \mathrm{mg} / 100 \mathrm{~g}$ for LSS seasons. The average inter seasonal change for $\mathrm{HCN}$ was $0.43 \%$.Phytate content ranged from ESS $0.80 \mathrm{mg} / 100 \mathrm{~g}$; MSS $1.0 \mathrm{mg} / 100 \mathrm{~g}$ to LSS $23 \mathrm{mg} / 100 \mathrm{~g}$. Increases in phytate content between the early season and mid-season fruiting was $50 \%$. Further rise of $0.7 \mathrm{mg} / 100 \mathrm{~g}$ was observed for LSS season phytate content. Phytate values of samples were lower than the values reported for soybean. Tannin contents of the seasons showed little variations among season. Decline in Tannin content (1.98 $-1.17 \mathrm{mg} / 100 \mathrm{~g}$ ) occurred at the late season fruiting. The oxalate content showed initial rise $(2.43 \%)$ from ESS fruiting to mid fruiting period, then declined by $6 \%$ decline. The mid season and late season seeds showed higher oxalate contents than the early season fruiting seeds samples. The alkaloid contents ranged from $0.47 \mathrm{mg} / 100 \mathrm{~g}$ to $0.33 \mathrm{mg} / 100 \mathrm{~g}$. The values were comparable among the season. The saponnin contents of early season and midseason seeds were comparable. The late season saponnin contents was higher but not significant $(\mathrm{p}>0.05)$. The phenols content ranged from ESS, $0.77 \mathrm{mg} / 100 \mathrm{~g}, \mathrm{MSS}$, $0.57 \mathrm{mg} / 100 \mathrm{~g}$ and $1.80 \mathrm{~g} / 100 \mathrm{~g}$ for LSS seeds. The late fruiting season phenolic content was significantly higher $(p<0.05)$ than the phenolic contents of other seasons. An initial decrease in phenolic was observed at mid season seeds.

Anti-nutrient values of this study showed that $\mathrm{HCN}$, Phytate, oxalate and Tannin contents were lower than 
values (Oxalate $28.7 \mathrm{mg}$. Tannin $18.09 \mathrm{mg}$, Phytate 8.33 , HCN $9.80 \mathrm{mg} / 100 \mathrm{~g}$ ) reported for velvet beans [28] and for peanuts [29]. Thus African breadfruits seeds are nutritionally better than lima and velvet beans. Alkaloids compositions of the test seeds showed a fairly distributed pattern over the fruitng seasons.

The tolerable limits for anti-nutrients per $1 \mathrm{~kg}$ body weight are HCN 50mg, Phytate $250-500 \mathrm{mg}$, Tannin $20 \mathrm{mg}$, Oxalate $3-5 \mathrm{mg}$ [30].

Observed changes in anti-nutrient content though not significant $(p<0.05)$ but for oxalate and saponin have been reported to be related to environmental factors such as light, moisture, temperature, seed maturity, factors among others $[4,31,32]$.

Anti-nutrients at low concentrations confer some health benefits in humans. The health benefits of anti-nutrients are derived from their affirnity for metabolic ions, disruption of nutrient metabolism through formation of complexes and interference on enzyme co-factors $[9,33]$. At low levels phytate, phenolic compounds and saponins exhibit some beneficial effects on human health. Such as anti-ageing, good health skin due to the rich composition of omega 3, lowering of blood glucose, lowering of cholesterol and alteration of ratios of $\mathrm{Ca} / \mathrm{Zn}$ and potassium/sodium. The ratio of $\mathrm{K} / \mathrm{Na}$ in human diet is an important risk factor for cardiovascular diseases [12]. Phytates slow down the rate of food digestion and subsequent absorption in the gut. Phenolic compounds chelate pro-oxidation metals, removes free radicals, prevent low density lipo-protein oxidation, boost immunity as well as prevention of DNA strand scission [4,14]. Saponins are strong hypo cholesterol and anti-microbial agents [27,34]. Saponnins in legumes are about $0.5 \%$ and $5 \%$ with low toxicity effects which explain the benefits of saponnins in human. Lower doses of alkaloids have been demonstrated to reduce blood pressure. Saponnin is also useful in treatment of hyper calciuria and lead poisoning [34]. Similar health benefits of saponnins have been observed with Tannin, including anti-oxidative actions, suppression of the proliferation of liver cells and protection of protein [35]. Both saponnins and tannins are important for weight reduction in humans $[39,40]$. Alkaloids exhibits antimicrobials, anti carcinogens and anti-ulcer [29] effects.

\subsection{Minerals Content of Samples}

The minerals content (Table 4) showed little variations in calcium, iron, magnesium, phosphorus, potassium, copper, sodium and zinc among the fruiting/seeding seasons. These seasonal variations were not significant $(p>0.05)$. The values of calcium and magnesium at late fruiting season showed some decreases. Calcium is needed by legume plants for the development of seeds. Magnesium is required in the photosynthetic activities involving chlorophyll by plants. These requirements could account for the low calcium and magnesium contents of seeds at late season harvesting [36]. Phosphorus Potassium - Sodium ratios exhibited an incremental trend in relationship. Phosphorus and potassium are needed by plants for protein and carbohydrate syntheses, and improved rate of seeding and seed quality. The mineral values were higher than values reported for maize and groundnuts [37].

Variations in mineral contents could be associated with the growth and metabolic requirements of Treculia africana. Evaluation of mineral elements dynamics showed that low content at early fruiting/seeding season reflected the excessive draw on minerals, followed by probable stabilization of the plant minerals pool at mid season fruiting and the marginal increases in mineral contents of seeds at late season. Previous studies on mineral elements of food crops attributed the values to variety and soil conditions

Table 4. Mineral content of seasonal samples of Treculia Africana seeds

\begin{tabular}{lcccccc}
\hline & \multicolumn{6}{c}{ Seasonal Content $(\mathrm{mg} / \mathrm{kg})$} \\
& Early & Mid & Late & Mean & SD & SE \\
\hline Calcium Ca & 25.98 & 26.10 & 20.00 & 24.03 & 3.49 & 2.01 \\
Iron Fe & 5.99 & 7.51 & 7.60 & 7.03 & 0.90 & 0.52 \\
Magnesium Mg & 369 & 348 & 280 & 332.33 & 46.52 & 26.86 \\
Phosphorus P & 490 & 550 & 560 & 532.33 & 37.86 & 21.86 \\
Potassium K & 1100 & 1077 & 1080 & 1085.66 & 12.50 & 7.32 \\
Copper $\mathrm{Cu}$ & 4.27 & 4.29 & 4.30 & 4.28 & 0.12 & 0.01 \\
Sodium Na & 7.50 & 8.06 & 8.06 & 7.86 & 0.30 & 0.17 \\
Zinc & 6.90 & 6.98 & 7.99 & 7.27 & 0.62 & 0.36 \\
\hline
\end{tabular}

RDA: Recommended Daily Allowances [19] SD = Standard Deviation, ESS $=$ Early season seeds, MSS $=$ Midseason seeds; LSS $=$ Late season seeds, $\mathrm{SE}=$ Standard error of mean .

Reports on the dynamics of mineral elements uptake by growing plants demonstrate complementary absorption patterns [3,6,9]. Magnesium, copper and iron are drawn for enzyme synthesis, chlorophyll formation and photosynthesis. Sodium, Potassium and phosphorus are used for carbohydrate and protein synthesis. Sodium may substitute for potassium. Zinc is an important factor in activation of enzymes, while zinc with phosphorus are vital for energy transfer. Calcium and sodium contents were lower the RDA for calcium and sodium [19].

\subsection{Statistical Summary}

The summary of the statistical results (Table 5) explained the observed relationships between proximate anti-nutrient contents of harvested Treculia africana seeds within and between fruiting seasons.

Table 5. Summary of Statistical Analysis of Table 2 and Table 3

\begin{tabular}{|c|c|c|c|c|c|c|c|c|}
\hline \multicolumn{9}{|c|}{ Pearson's Correlation $(r)>0.366$} \\
\hline Parameters & \multicolumn{2}{|c|}{$\begin{array}{c}\text { ESS } \\
\text { Between Within }\end{array}$} & \multicolumn{2}{|c|}{$\begin{array}{c}\text { MSS } \\
\text { Between Within }\end{array}$} & \multicolumn{2}{|c|}{$\begin{array}{c}\text { LSS } \\
\text { Between Within }\end{array}$} & Df & $\mathrm{F}$ \\
\hline Proximate & 1.0 & 1.0 & 1.0 & 1.0 & 1.0 & 1.0 & 17 & $10.36^{* *}$ \\
\hline Anti-Nutrient & 0.388 & 1.0 & 0.436 & 1.0 & 0.295 & 1.0 & 20 & $38.54 * *$ \\
\hline
\end{tabular}

$\mathrm{DF}=$ Degree of freedom. $* *$ denotes significant $(\mathrm{P}<0.05)$ relationships

ESS $=`$ Early season seeds; MSS = Mid season seeds; LSS $=$ Late seasons seeds. 
Statistical results showed significant relationships $\mathrm{p}<0.1$ ) between seasons and proximate, anti-nutrient of ESS, and significant relationship $(p<0.05)$ between proximate and anti nutrients for mid season seeds.

Seasonal variations in nutrient and anti-nutrients demonstrated positive correlation within and between seasonal seed groups. The observed changes in proximate and anti-nutrient values between fruiting seasons underscored seasonal effects on seed maturity and composition.

\section{Conclusion}

This study evaluated the changes in nutrients, antinutrients and mineral compositions of Treculia africana during its fruiting season and its implications on nutrition and health contributions of Treculia africana seeds in humans, as described by changes in composition at time of harvest. The changes in chemical composition were probably related to seasonal interactions of climatic variables .Such interactions significantly influenced some nutrients and anti-nutrients values. minerals content showed consistent and comparable values among seasons. The seasonal changes in nutrients,anti nutrients and minerals can be used to enhance the nutritional contributions and health management benefits of Treculia africana.

\section{References}

[1] Andriotis, V.M.E, Pike, M.J, Kular, B., Rawsthone, S. and Smith A. M. (2010). Starch Turnover in developing oil seed embryo. New Physiol. 187: 791-804.

[2] Fubara, E. P. B. O. Ekpo and Ekpete,O.A(2011). Evaluation of the Effects of Processing on the Mineral Contents of maize (Zea mays) and Groundnut (Arachis hypogea) Lib. Agri. Res. Cent. J. Intl. 2 (3): $133-137$

[3] Haggar (2009). Seasonal production of Andropogen gayamus I. Seasonal changes in yield components and chemical composition. J. Agric. Sci. 74 (3) 487-494.

[4] Petkova, S. Y. and Antova, G. N. (2015). Changes in the composition of pumpkins seeds (Gicuabita moschata) during development and maturation. Grases Aceit. 66 (1):058.

[5] Zubr, J. and Mathhaus, B. (2002). Effect of growth condition on fatty acids and tocopherol in Camelina sativa oil. Ind. Crops. Prod. 15: $155-162$

[6] Dupont. F. M. and Itenbach, B.S, (2003). Molecular and Biochemical Impact of Environmental Factors on Wheat grain development and protein synthesis. J. Cereal Sci.

[7] Kirkhus, B., Lundon, A.R, Haugen, J.E., Vogt. G. Borge, G. I. A and Henriksen, B. I. F. (2013). Effects of environmental factors on edible oil quality of organically grown Camelina sativa. J. Agric Food. Chem. 61: 3179-3185.

[8] Nwabueze T. U. (2009). Kernel extraction and Machine Efficiency in delulling parboiled African breadfruit (Treculia africana) whole seed. J. Food Quality 32: 669-683.

[9] Fasasi, O. S. Eleyimi A.R, Fasasi, A.R and Kasim,O.R. (2003). Chemical properties of raw and processed breadfruit (Treculia africana) seats. African crop science proceedings 6: 547-551.

[10] Osabor, V. N., Ogar, D.A., Okafor, P.C. and Egbuna G.E. (2009). Profile of the African breadfruit (Treculia africana) Pak. J. of Nutr. 8 (7): 1005-1008

[11] Ezengige, G. (2015). African breadfruit (Treculia african), Ukwa is Igbo is an excellent food for Patients of heart disorder and diabetes. Available www.healthbubbles.com/gb/pp = 2146. Accessed 20/03/2017.
[12] Shahidl (1997). Beneficial helath effects and drawbacks of antinutrients and phytochemicals in food. An overview. Available. www.bk-1997-0662. Ca. Accessed 12/11/2012.

[13] Solomon, D. (2005). Nutritive value of three potential complementary foods based on cereals and legumes. Afr. J. Food Sci. and Nutrition. 5 (2):1-14.

[14] Olayemi, F. O. (2010). A review of some causes of male infertility Afri. J. of Biotechnola (20): 2834-3842.

[15] Anyabor G.N Ogunwenmo K. O, Oyelana, R., Ajayi D. and Dagana J. (2009). Chemical Analysis of Groundnuts. Pak. J. of Nutr. 8 (3): 269-272.

[16] NCSU (2013). Mineral Requirements in Plants. Available www.ncsu/950051/Lee5htm .accessed12/12/2016.

[17] Habtamu, F. G and Negussie,R (2014). Nutritional factors in plant foods: Potential health benefits and adverse effects. Global Adv. Res. J. Food Sci and Technol. 3 (4): 103-112.

[18] World Health Organization (2010). Toxicological evaluation of certain food additives and naturally occurring toxicaulo who food Additive Series. 30. World Health Organization. Geneva.

[19] FAO/WHO (1985). Preparation and use of Food-Based dietary Guidelines: Report of a joint $\mathrm{FAO} / \mathrm{WHO}$ consultant WHO Technical Report Series 880. Geneva.

[20] Holmes, R.P, Goodman H. O. and Assimos D.G (2001). Contribution of dietary oxalates to urinary oxalate secretion excretion. Kidney Intl.. 59 (1): 270-276.

[21] Hambige (2000). Human zinc deficiency. J. of Nutr. 130: 1344513495.

[22] Shamsuddin, A. M. (2002). Anti-cancer function of phytic acid. Intl. is food sci. and technol. 37 (7): 769-782.

[23] Udensi, E. A., Ekwu, F. C. and Isinguzo, J. N. (2007). Antinutrient factors of vegetable cowpea seeds during thermal processing. Pakistan J. Nutr. 6 (2): 194-197.

[24] Ahn, J. H., Robertson, B. M, Elliot, R. Gutteridge RC and Ford, C. W. (1989). Quality Assessment of Tropical Legumes degradation. Anim. Feed Sci. Technol. 27: 147-156.

[25] Lowa State University (2001). Requirments for plant Growth Community Tree Steward Program Urban and Community Forest Council. Lowa .US

[26] Salunkhe, B. K. (2006). Anti-nutritional factors of different grain legumes grown in North Maharastra. J. Food. Sci. 43 (5):519-512.

[27] Jansman, A. J., Hill, E. D., Huisman, J. and Vander Poet,A.F (1998). Recent advances of Research in Anti-nutritional factors in legume seeds. Wageningen Uni. Pers. 76.

[28] Grainsa, (2012). Factors affecting wheat seed germination. Available www.grainsa.co.za/factors affecting wheat seed. Accessed 12/12/2015

[29] Mohammadi, A. T., A. Sani and Kamale, H. (2012).Seasoned variations in chemical composition, anti-oxidant activity and total phenolic content of artemisa absinthum. Pharmcognosy Res. Available www.nobi.n/m.gov/pmc/pmc 4660511. Accessed $10 / 11 / 2014$.

[30] Friedman, M. (2001). Nutritional and health benefits of soy protein. J. Agri. Food. Chem. 49: 1069-1086.

[31] Ayoola P.B and Adeyeye. A. (2010). Effect of heating on the chemical composition and physicochemical properties of Arachis hypogeace seeds flour and oil. Pak J. of Nutr. 9 (8): 751-754,

[32] Simee W. (2011). Isolation and determination of Anti-nutritional compounds from root to shell of peanuts (Arachis hypogaea) J. Disper. Sci. Technol. 28: 341-347.

[33] Bingham, S. (1977). Dictionary of nutrition. Barrie and Jenkins. London.

[34] Bora, P. (2014). Anti-nutritional factors and their effects. J. Acad. Ind. Res. 3 (6):285-291.

[35] AOAC (2000). Official methods of Analysis Assoc. of Official Analtical Chemists. Washington DC USA.

[36] Pearson D. (1976). The chemical Analysis of foods 7th edu. Churchhill Livingstone. Edinburgh

[37] AOAC (1998). Official methods of Analysis Assoc. of Official Analtical Chemists. Washington DC USA.

[38] Hathcook, J. N. (2008). Anti-nutrients in nutrient and toxicological consequences of food processing. Friedman M. (ed). Plenum Press. NY USA. 273-279.

[39] John, S. K., Arienansalem, D., Yeung, Y., Kakuda, G. Mittal and Yueming.J (2004). Saponins from edible legumes chemistry, processing and Health benefits. J. Med. Food. 7 (1): 67-78. 
[40] Kao, T. H., Huang, S. C., Inbara;, B. S., and Chen, B. H. (2008). Determination of flavonoiods and Saponins in Gynostemmapentaphyllum. J. Anal. Chemica. Acta 626: 200-211.

[41] Komal, P. and Darshen, (2000). Anti-nutrients and digestibility (in vitro) of soaked, dehulled and germinated cowpea. Nutrition and Health. 14 (2): 109-117.

[42] Lafond, G. P., Irvine, B. and Johnston, A. M. (2005). Impact of agronomic factors on seed yield formation and quality in flax. Canadian J. Plant Sci. 88.
[43] Olaofe, O., Okiribiti, B. Y., and Aremu, M. O. (2008). Chemical evaluation of the nutritive value of smooth luffa (Luffa cylindrical) Seed Kernel. J. Envi. Agric. Food. Chem. 7 (10): 3444-52.

[44] Yacout, H. (2016). Anti-nutrient factors and its roles in Animal nutrition. J. Dairy. Vet. Anim. Res. 4 (1): 1-3. 